\title{
Front Matter: Volume 7113
}

, "Front Matter: Volume 7113," Proc. SPIE 7113, Electro-Optical and Infrared Systems: Technology and Applications V, 711301 (24 October 2008); doi: 10.1117/12.816764

SPIE. Event: SPIE Security + Defence, 2008, Cardiff, Wales, United Kingdom 


\title{
PROCEEDINGS OF SPIE
}

\section{Electro-Optical and Infrared Systems: Technology and Applications $V$}

\author{
David A. Huckridge \\ Reinhard R. Ebert \\ Editors
}

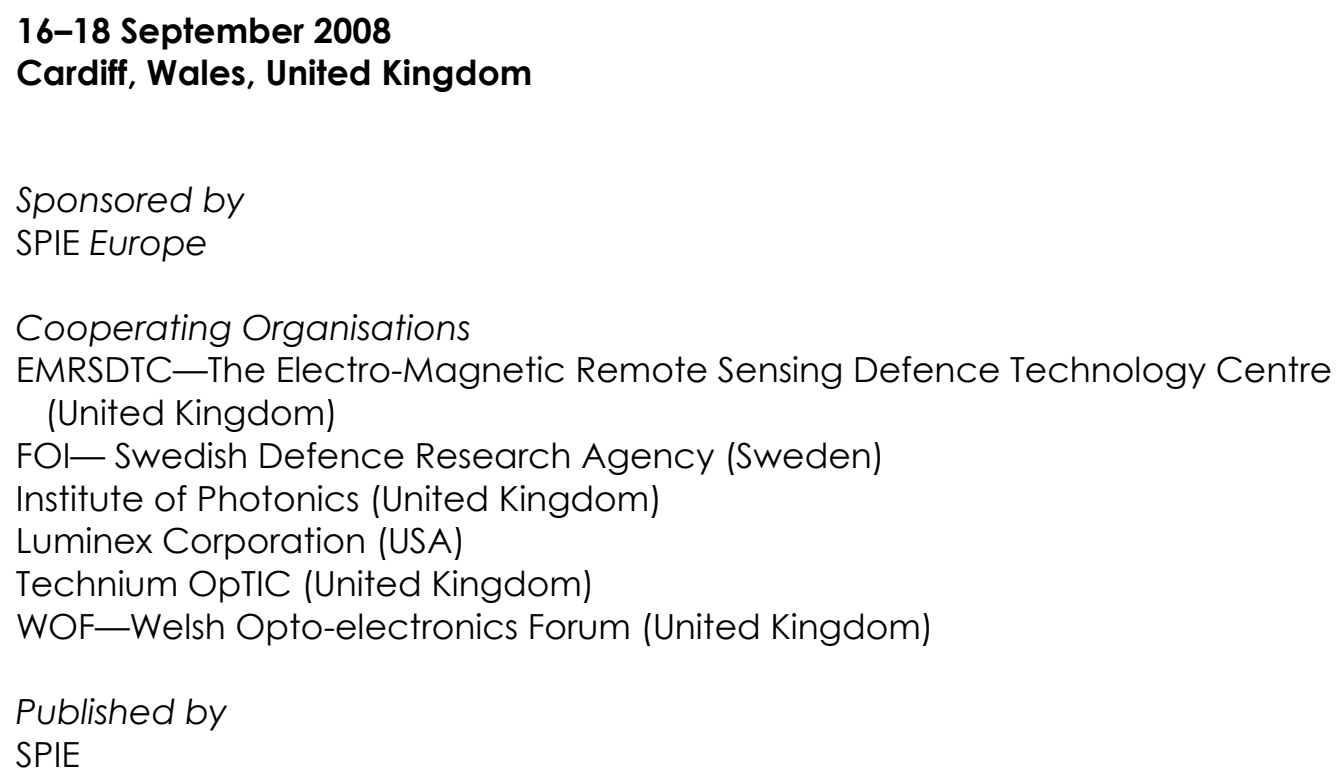

Volume 7113 
The papers included in this volume were part of the technical conference cited on the cover and title page. Papers were selected and subject to review by the editors and conference program committee. Some conference presentations may not be available for publication. The papers published in these proceedings reflect the work and thoughts of the authors and are published herein as submitted. The publisher is not responsible for the validity of the information or for any outcomes resulting from reliance thereon.

Please use the following format to cite material from this book:

Author(s), "Title of Paper," in Electro-Optical and Infrared Systems: Technology and Applications V, edited by David A. Huckridge, Reinhard R. Ebert, Proceedings of SPIE Vol. 7113 (SPIE, Bellingham, WA, 2008) Article CID Number.

ISSN 0277-786X

ISBN 9780819473455

Published by

SPIE

P.O. Box 10, Bellingham, Washington $98227-0010$ USA

Telephone +1 3606763290 (Pacific Time) · Fax +1 3606471445

SPIE.org

Copyright (c) 2008, Society of Photo-Optical Instrumentation Engineers

Copying of material in this book for internal or personal use, or for the internal or personal use of specific clients, beyond the fair use provisions granted by the U.S. Copyright Law is authorized by SPIE subject to payment of copying fees. The Transactional Reporting Service base fee for this volume is $\$ 18.00$ per article (or portion thereof), which should be paid directly to the Copyright Clearance Center (CCC), 222 Rosewood Drive, Danvers, MA 01923. Payment may also be made electronically through CCC Online at copyright.com. Other copying for republication, resale, advertising or promotion, or any form of systematic or multiple reproduction of any material in this book is prohibited except with permission in writing from the publisher. The CCC fee code is 0277-786X/08/\$18.00.

Printed in the United States of America.

Publication of record for individual papers is online in the SPIE Digital Library.

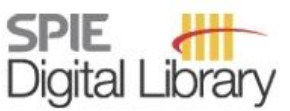

SPIEDigitalLibrary.org

Paper Numbering: Proceedings of SPIE follow an e-First publication model, with papers published first online and then in print and on CD-ROM. Papers are published as they are submitted and meet publication criteria. A unique, consistent, permanent citation identifier (CID) number is assigned to each article at the time of the first publication. Utilization of CIDs allows articles to be fully citable as soon they are published online, and connects the same identifier to all online, print, and electronic versions of the publication. SPIE uses a six-digit CID article numbering system in which:

- The first four digits correspond to the SPIE volume number.

- The last two digits indicate publication order within the volume using a Base 36 numbering system employing both numerals and letters. These two-number sets start with 00, 01, 02, 03, 04, 05, $06,07,08,09,0 \mathrm{~A}, 0 \mathrm{~B} \ldots \mathrm{OZ}$, followed by $10-1 \mathrm{Z}, 20-2 \mathrm{Z}$, etc.

The CID number appears on each page of the manuscript. The complete citation is used on the first page, and an abbreviated version on subsequent pages. Numbers in the index correspond to the last two digits of the six-digit CID number. 


\section{Contents}

ix Conference Committee

\section{SESSION $1 \quad$ IR DETECTORS AND SENSORS}

711302 Latest developments in compact IR cooled detectors [7113-01]

F. Pistone, M. Vuillermet, Sofradir (France)

711303 Uncooled amorphous silicon 1/4 VGA IRFPA with $25 \mu \mathrm{m}$ pixel-pitch for high-end applications [7113-02]

C. Minassian, J. L. Tissot, M. Vilain, O. Legras, S. Tinnes, A. Crastes, P. Robert, B. Fieque, ULIS (France)

711304 Advanced infrared optical measurements at Sofradir [7113-03]

S. Verdet, D. Leclercq, A. Cuelhe, G. Query, D. Billon-Lanfrey, Sofradir (France)

711306 Investigations of reactively sputtered $\mathrm{TiO}_{2-\delta}$ films for microbolometer applications [71 13-05] M.-H. Kwon, K. Yang, Y.-S. Park, Y.-H. Kim, H. Chung, i3system Corp. (South Korea)

\section{SESSION 2 ACTIVE SYSTEMS AND PROPAGATION}

711307 3D imaging with range gated laser systems using speckle reduction techniques to improve the depth accuracy [7113-07]

B. Göhler, P. Lutzmann, G. Anstett, Research Institute for Optronics and Pattern Recognition (Germany)

711308 Measurement of atmospheric MTF in a littoral environment [7113-08]

D. J. Griffith, F. P. J. le Roux, Council for Scientific and Industrial Research (South Africa);

P. B. W. Schwering, TNO Defence, Security and Safety (Netherlands); M. Holloway, Council for Scientific and Industrial Research (South Africa)

\section{SESSION 3 EO AND IR SYSTEMS: TECHNOLOGY AND APPLICATIONS IN UK-KEYNOTE SESSION}

7113 OC Discriminative sensing techniques (Keynote Paper) [7113-13]

K. Lewis, Sciovis Ltd. (United Kingdom)

\section{SESSION 4 EO AND IR SYSTEMS: TECHNOLOGY AND APPLICATIONS IN UK I}

7113 OD The principles and roles of hybrid optical/digital codecs in imaging (Invited Paper)

[7113-14]

A. R. Harvey, G. Muyo, M. Demenikov, Heriot-Watt Univ. (United Kingdom) 
$71130 \mathrm{O} \quad$ Hollow optical waveguide devices and systems (Invited Paper) [7113-15]

R. M. Jenkins, B. J. Perrett, M. E. McNie, E. D. Finlayson, R. R. Davies, J. Banerji, A. R. Davies, QinetiQ Ltd. (United Kingdom)

7113 OF A versatile wide dynamic range pixel with an improved low-light sensitivity [7113-16] H.-Y. Cheng, S. Collins, Univ. of Oxford (United Kingdom)

$71130 \mathrm{R}$ Results from the UK 3rd generation programme: Albion [7113-17]

R. K. McEwen, C. Axcell, P. Knowles, K. P. Hoade, M. Wilson, SELEX Galileo (United Kingdom); P. N. J. Dennis, P. Backhouse, N. T. Gordon, QinetiQ Ltd. (United Kingdom)

$7113 \mathrm{OH} \quad$ Low noise InAs avalanche photodiodes for high sensitivity FPAs [7113-18]

A. R. J. Marshall, C. H. Tan, M. J. Steer, J. P. R. David, The Univ. of Sheffield (United Kingdom)

\section{SESSION $5 \quad$ EO AND IR SYSTEMS: TECHNOLOGY AND APPLICATIONS IN UK II}

71130 Infrared photodiodes based on Type-II strained layer superlattices [7113-19]

S. D. Das, Y. L. Goh, C. H. Tan, J. P. R. David, The Univ. of Sheffield (United Kingdom);

J.-B. Rodriguez, E. A. Plis, Y. D. Sharma, H. S. Kim, S. Krishna, The Univ. of New Mexico (United States)

$71130 \mathrm{~J} \quad$ Multiple stack quantum dot infrared photodetectors [7113-20]

P. Vines, C. H. Tan, J. P. R. David, The Univ. of Sheffield (United Kingdom); R. S. Attaluri,

T. E. Vandervelde, S. Krishna, The Univ. of New Mexico (United States)

7113 OK Discriminative imaging using a LWIR polarimeter [7113-21]

B. Connor, I. Carrie, R. Craig, J. Parsons, Thales Optronics Ltd. (United Kingdom)

$7113 \mathrm{OL} \quad$ Multispectral-polarimetric sensing for detection of difficult targets [7113-22]

W. Hubbard, G. Bishop, T. Gowen, BAE Systems (United Kingdom); D. Hayter, G. Innes, QinetiQ Ltd. (United Kingdom)

$71130 \mathrm{M} \quad$ Miniature imaging devices for airborne platforms [7113-23]

L. C. Laycock, V. A. Handerek, BAE Systems (United Kingdom)

$71130 \mathrm{~N} \quad$ Sub-100g uncooled thermal imaging camera design [71 13-24]

A. Brown, Thermoteknix Systems Ltd. (United Kingdom)

7113 OP Accelerating image processing capability using graphics processors [7113-26]

J. Dale, G. Cain, Vision4ce Ltd. (United Kingdom); B. Zell, Vision4ce LLC. (United States)

\section{SESSION 6 SENSORS SYSTEMS AND TECHNOLOGIES I}

$71130 Q \quad$ Mitigating ground-based sensor failures with video motion detection [71 13-27]

R. E. Macior, Air Force Research Lab. (United States); J. P. Knauth, Critical Imaging, LLC (United States); S. M. Walter, Air Force Research Lab. (United States); R. Evans, Critical Imaging, LLC (United States) 
7113 OR Surveillance of borders, coastlines and harbours (SOBCAH): a European commission preparatory action on security research [7113-28]

D. J. Clarke, E. Davis, A. G. Varco, SELEX Galileo (United Kingdom)

7113 OS Electro-optical systems to accurately align (boresight) laser designator, FLIR, and CCD on the ground before the mission [7113-29]

D. Cabib, A. Segal, J. Dolev, CI Systems Ltd. (Israel)

\section{SESSION 7 SENSORS SYSTEMS AND TECHNOLOGIES II}

7113 OU Test projectors to demonstrate the performance of IR missile warning sensors [7113-31]

T. Roth, J. Barth, S. Gadaleta, EADS-Defence Electronics (Germany)

$71130 \mathrm{~V}$ Controllable time dependent and dual band emission infrared source to test missile warning systems in flight [71 $113-32]$

D. Cabib, L. Davidzon, A. Gil, Cl Systems Ltd. (Israel)

7113 OW Designing a 1.7-5.3 $\mu \mathrm{m}$ athermalized lens [7113-33]

R. Bardazzi, SELEX Galileo (Italy)

$71130 \mathrm{X}$ Thermal infrared optical metrology using quadri-wave lateral shearing interferometry [7113-34]

S. Velghe, D. Brahmi, W. Boucher, B. Wattellier, PHASICS S.A. (France); N. Guérineau,

R. Haïdar, J. Primot, ONERA, Office National d'Etudes et de Recherches Aérospatiales (France)

7113 OY Wideband protection filter (WPF) integrated within optical systems [71 13-35]

G. Ritt, B. Eberle, R. Ebert, FGAN-FOM, Research Institute for Optronics and Pattern

Recognition (Germany); T. Fisher, B. Nemet, M. Oron, A. Donval, KiloLambda Technologies, Ltd. (Israel)

$71130 Z$ Continuous laser beam steering with micro-optical arrays: experimental results [7113-37] J. Bourderionnet, Thales Research and Technology (France); M. Rungenhagen, Diehl BGT Defence GmbH \& Co. KG (Germany); D. Dolfi, Thales Research and Technology (France); H. D. Tholl, Diehl BGT Defence GmbH \& Co. KG (Germany)

\section{SESSION 8 SPECTRAL SENSING}

711310 Performance and examples of measurements of a mid infrared interferometric hyperspectral imager [7113-38]

D. Cabib, Cl Systems Ltd. (Israel)

711311 Multispectral observations of marine mammals [7113-39] J. Schoonmaker, J. Dirbas, Y. Podobna, T. Wells, C. Boucher, D. Oakley, Advanced Coherent Technologies, LLC (United States)

711312 Methodology for accurate multi-spectral signature measurement [7113-40] M. Y. Engel, A. D. Devir, I. Mendelewicz, Institute for Advanced Research and Development (Israel) 
711313 Neural network approaches for multi-spectral missile discrimination [7113-41]

M. C. Altinigneli, S. Gadaleta, EADS Deutschland GmbH (Germany)

711314 Detecting anomalous objects in hyperspectral data using segmentation [7113-42]

H. Blecher Segev, S. R. Rotman, D. G. Blumberg, Ben-Gurion Univ. of the Negev (Israel)

711315 Coping with mixtures of backgrounds in a sliding dual window anomaly detection algorithm [7113-43]

L. Boker, S. R. Rotman, D. G. Blumberg, Ben-Gurion Univ. of the Negev (Israel)

711316 Spatial and temporal point tracking in real hyperspectral images [7113-44]

B. Aminov, O. Nichtern, S. R. Rotman, Ben-Gurion Univ. of the Negev (Israel)

SESSION 9 IMAGE PROCESSING

711317 A new method for observer-based evaluation of object detectability using image sequences taken by approaching sensors [7113-45]

E. Maver, P. Koffler, Research Institute for Optronics and Pattern Recognition (Germany)

711318 Approaches for detecting behavioural anomalies in public areas using video surveillance data [7113-46]

C. Brax, Saab AB (Sweden) and Univ. of Skövde (Sweden); R. Laxhammar, Saab AB

(Sweden); L. Niklasson, Univ. of Skövde (Sweden)

711319 Adapting full motion video data for the real world [7113-47]

R. E. Macior, Air Force Research Lab. (United States); G. A. Bright, Computer Sciences Corp. (United States); S. M. Walter, Air Force Research Lab. (United States)

$71131 \mathrm{~A}$ Image enhancement for noisy color imagery [7113-48]

J. Dijk, R. J. M. den Hollander, TNO Defence, Security and Safety (Netherlands)

\section{POSTER SESSION}

$71131 \mathrm{~B}$ The influence of surrounding temperature on non-uniformity response of uncooled infrared focal panel arrays [7113-49]

H.-M. QU, Q. Chen, Z. Guan, Nanjing Univ. of Science and Technology (China)

7113 1C A far infrared/terahertz micromechanical sensor based on surface plasmons resonance [7113-50]

J. Hastanin, Y. Renotte, Defise, Univ. de Liège (Belgium); K. Fleury-Frenette, J. M. Defise, Ctr. Spatial de Liège (Belgium); S. Habraken, Univ. de Liège (Belgium) and Ctr. Spatial de Liège (Belgium)

7113 1D Fast estimation model for the observation range in thermovision at variable thermal contrasts [7113-51]

O. C. Borcan, C. A. Spulber, Pro Optica S.A. (Romania)

$71131 \mathrm{~F} \quad$ Long-range PIR detector used for detection of crawling people [7113-53]

M. Kastek, T. Sosnowski, H. Polakowski, M. Dąbrowski, T. Orżanowski, Military Univ. of Technology (Poland) 
7113 IG Method of objects detection employing passive IR detectors for security systems [7113-54] T. Sosnowski, H. Madura, M. Kastek, T. Piatkowski, E. Powiada, Military Univ. of Technology (Poland)

$71131 \mathrm{H}$ Simulated and measured performance of $\mathrm{HgCdTe}$ focal plane arrays [71 13-55] G. V. Chekanova, Federal State Unitary Enterprise ALPHA (Russia); A. A. Drugova,

V. Kholodnov, Institute of Radio Engineering and Electronics (Russia); M. S. Nikitin, Federal State Unitary Enterprise ALPHA (Russia)

Author Index 
Downloaded From: https://www.spiedigitallibrary.org/conference-proceedings-of-spie on 26 Apr 2023

Terms of Use: https://www.spiedigitallibrary.org/terms-of-use 


\title{
Conference Committee
}

\author{
Symposium Chair \\ David H. Titterton, Defence Science and Technology Laboratory \\ (United Kingdom) \\ Conference Chairs \\ David A. Huckridge, QinetiQ Ltd. (United Kingdom) \\ Reinhard R. Ebert, Forschungsgesellschaft für Angewandte \\ Naturwissenschaften e.V. (Germany) \\ Program Committee \\ Christopher C. Alexay, Chris Alexay Optical Design (United States) \\ Jan Y. Andersson, Acreo AB (Sweden) \\ Gordon A. Cain, Octec Ltd. (United Kingdom) \\ David J. Clarke, SELEX Sensors and Airborne Systems Ltd. (United \\ Kingdom) \\ Stefania De Vito, SELEX Sensors and Airborne Systems SpA (Italy) \\ Peter N. J. Dennis, QinetiQ Ltd. (United Kingdom) \\ Per S. W. Fredin, Saab Bofors Dynamics AB (Sweden) \\ Norman S. Kopeika, Ben-Gurion University of the Negev (Israel) \\ José M. López-Alonso, Universidad Complutense de Madrid (Spain) \\ John F. Parsons, Thales Optronics Ltd. (United Kingdom) \\ Stanley R. Rotman, Ben-Gurion University of the Negev (Israel) \\ Christopher W. Slinger, QinetiQ Ltd. (United Kingdom)
}

Session Chairs

$1 \quad$ IR Detectors and Sensors

Reinhard R. Ebert, Forschungsgesellschaft für Angewandte Naturwissenschaften e.V. (Germany)

2 Active Systems and Propagation

Norman S. Kopeika, Ben-Gurion University of the Negev (Israel)

John F. Parsons, Thales Optronics Ltd. (United Kingdom)

3 EO and IR Systems: Technology and Applications in UK-Keynote Session

David A. Huckridge, QinetiQ Ltd. (United Kingdom)

David J. Clarke, SELEX Sensors and Airborne Systems Ltd. (United Kingdom) 
$4 \quad$ EO and IR Systems: Technology and Applications in UK I

David A. Huckridge, QinetiQ Ltd. (United Kingdom)

David J. Clarke, SELEX Sensors and Airborne Systems Ltd. (United Kingdom)

$5 \quad$ EO and IR Systems: Technology and Applications in UK II

David A. Huckridge, QinetiQ Ltd. (United Kingdom)

David J. Clarke, SELEX Sensors and Airborne Systems Ltd. (United Kingdom)

6 Sensors Systems and Technologies I

Stefania De Vito, SELEX Sensors and Airborne Systems SpA (Italy)

7 Sensors Systems and Technologies II

Stefania De Vito, SELEX Sensors and Airborne Systems SpA (Italy)

$8 \quad$ Spectral Sensing

Stanley R. Rotman, Ben-Gurion University of the Negev (Israel)

Christopher C. Alexay, Chris Alexay Optical Design (United States)

$9 \quad$ Image Processing

David A. Huckridge, QinetiQ Ltd. (United Kingdom)

Reinhard R. Ebert, Forschungsgesellschaft für Angewandte Naturwissenschaften e.V. (Germany) 